\section{Brazil bans conference on Amazon biology}

THE Brazilian government has refused permission for a conference on the evolution of biological systems in the Amazon region, organised by the Association for Tropical Biology, which was to have opened next week in Manaus, the region's major city.

Although no official reason for the decision has been given, scientists in the US believe that the military government may have been concerned that those attending the meeting would use it as an occasion to criticise the environmental effects of Brazil's current development policies--even though the conference itself will deal primarily with events that took place over 5,000 years ago.

The conference has bcen hastily rearranged to take place in Macuto, on the Venezuclan coast outside Caracas, and has received the support of the Venezuelan Ministry of the Environment. It has been convened to discuss biological models of diversification in the tropics. Speakers will address topics

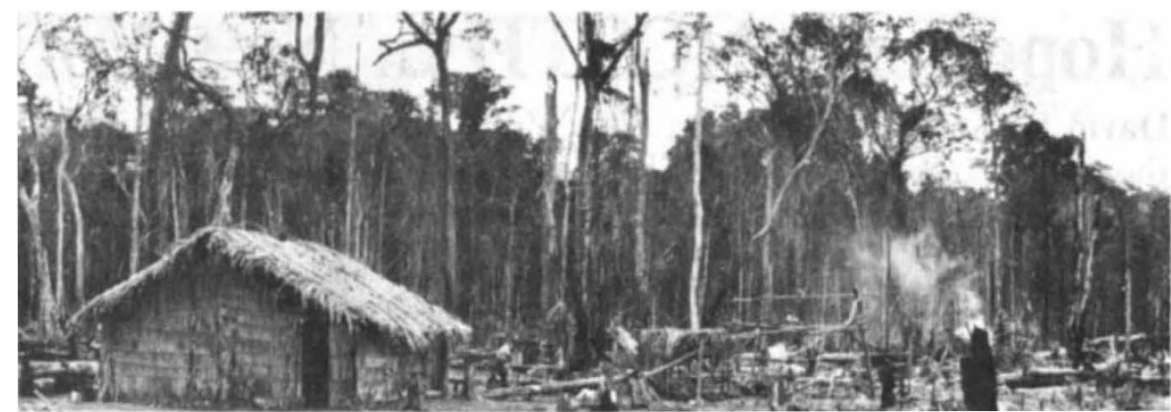

The Amazon: science can help protect its environment

such as the relationship between climatic change and species differentiation in the Amazon and its surrounding savannah region.

All the original speakers-including a number from Brazil-are expected to attend as planned. However, the change of location may prevent the participation of some Brazilian research workers and students, for whom lengthy visa negotiations, as well as the deposit of a large sum of money, are necessary for foreign private travel.

"This conference will bring together specialists in disciplines ranging from archaeology to entomology and genetics. Everything is now working together, and we are coming up with some exciting material, such as the correlation between archaeological sites and past climatic changes," Dr Clifford Evans, curator of South American archaeology at the Smithsonian Institution in Washington, DC, and one of the main organisers of the conference, said last week.

The military government's decision, which was taken on the advice of the National Security Council, has provoked a storm of protest in the Brazilian press, from which censorship has only recently been lifted. Critics, including a number of eminent scientists, have accused the government of interfering with academic freedom, and of ignoring how science is necessary to preserve the cnvironmental integrity of the Amazon region.

David Dickson

\title{
Second thoughts on study of nuclear risk
}

The Boston-based Union of Concerned Scientists has called for the temporary shutdown of 16 US nuclear power plants for safety modifications, in the light of evidence that previous estimates of "low probability" risks may have bcen unjustified.

This demand follows the decision of the Nuclear Regulatory Commission to withdraw its support from important parts of a study published by the commission three years ago on the safety of nuclear reactors, which indicated that the risks from nuclear power were much less than from other man-made activities.

The study was carried out for the NRC by a team headed by Professor Norman Rasmussen, of the Massachusetts Institute of Technology. On its publication in 1975, the NRC described the report as a "soundly based and impressive work"

The conclusions of what has become widely known as the Rasmussen Report have heen frequently used by supporters of nuclear power to defend existing and proposed programmes. However, criticism by others of the report's methodology and its conclusions - in particular by Congressman Morris Udall. chairman of the House Committee on Interior and Insular Affairs-led the NRC to appoint a review group headed by Professor Harold Lewis of the University of California, Santa Barbara.

In its report, which was presented to the commission in September, the review groups said that it found the methodology used in the study-based on a fault-tree/event-tree form of analysis-to be basically sound. However it had a number of reservations about the way that the results of the analysis had been presented.

In particular, the committee criticised the narrow limits which the Rasmussen report had placed on estimates of the probability of a melt-down of the reactor core. The reasons for understating the error band. said the committee. included an inadequate data base, a poor statistical treatment. and an inconsistent propagation of uncertainties throughout the calculation.

The review committee also criticised the executive summary of the report-the part which has been most widely quoted in public discussions. The committee says that the summary did not sufficiently emphasise the uncertainties involved in calculating the probability of risk and that this might have led readers to a "misplaced confidence" in the validity of the risk estimated.

In a statement issued last week. the NRC commissioners say that they accept the criticisms of the review committee, and as a result have withdrawn any explicit or implicit endorsement of the report's executive summary.

On accident probabilities, the NRC says that the absolute values of risk in the Rasmussen report "should not be used uncritically either in the regulatory process or for public policy purposes". (The report states, for example, that nuclear power plants were about 10,000 times less likcly to produce fatal accidents than man-made non-nuclear activities.)

The NRC's decision to support the L.ewis Review Committee's findings has prompted the 65,000 strong Union of Concerned Scientists, which has been among Rasmussen's most vocal and persistent critics, to demand additional safety precautions at 16 plants where, they claim. there is evidence that the report was used to justify the acceptance of current safety procedures.

"Although the risks are still indeterminate. the uncertainty band includes an area of risk which is unacceptable. and it is on this basis that we are asking for the shutdowns". Dr Henry Kendall. Professor of Physics at Massachusetts Institute of Technology, said last week.

David Dickson 